\title{
The Harmonization of Professional Teaching and Professional-Competency Training in Financial Management
}

\author{
Wei Lin, Cao Shan, Song Yu \\ School of Business, Tianjin University of Finance \& Economics, Tianjin, China \\ Email: weilin63@126.com, caoshan2925@163.com
}

Received 6 August 2014; revised 10 October 2014; accepted 4 November 2014

Academic Editor: Shaodan Luo, Wuhan Irvine Culture and Communication, China

Copyright (C) 2014 by authors and Scientific Research Publishing Inc.

This work is licensed under the Creative Commons Attribution International License (CC BY).

http://creativecommons.org/licenses/by/4.0/

(c) (i) Open Access

\begin{abstract}
With the expansion in enrollment scale of financial management and the increase in the pressure of job-hunting, more and more schools start to analyze the problem regarding how to cultivate excellent financial management talents who meet the social demand, and how to build their own features and brands (Zhang Junrui \& Liu Donglin, 2005). In this paper, according to Chinese certified public accountants competence guide and starting from the professional competency model, we analyzed how to attain harmony between knowledge imparting and students' vocational ability training in the professional education in financial management, and discussed the necessity of the coordination in the professional education in financial management and students' vocational ability training. Finally, we discovered four pathways to harmonize financial management professional teaching and professional competency training: 1) establishment of dynamic course modules based on demand orientation; 2) reform of teaching methods; 3) bringing practical experts into the classroom; 4) establishment of a multi-dimensional students learning quality evaluation.
\end{abstract}

\section{Keywords}

Professional Teaching, Professional Competence, Harmonizing

\section{Competency Model}

\subsection{The Definition of Competency}

The competency refers to the personalities of stand-out performers in a special post, environment, and cultural

How to cite this paper: Wei Lin, Cao Shan, \& Song Yu (2014). The Harmonization of Professional Teaching and Professional-Competency Training in Financial Management. Chinese Studies, 3, 165-170.

http://dx.doi.org/10.4236/chnstd.2014.34023 
atmosphere. It could be objectively measured. These personalities include the following several aspects:

1) Knowledge: the organization and utilization of useful information in an occupation area.

2) Skill, the ability to get things done.

3) Social role: the image which a person wants to show in front of others.

4) Self-concept: the recognition and perception of one's own identity.

5) Personal characteristics: the physical characteristics and typical behaviors of a person.

6) Motivation/need: the natural and stable thoughts which determine a person's external behavior.

Competency Model includes, firstly, the portion of "knowledge" and "skill” regarding what one "should know" and "should be" and, secondly, the emotional intelligence portion of "value, self-image, personality, and internal drive". Knowledge and skills, etc., are obvious, prominent, and easy to be measured, but the factors which determine the chance or the success are hard to measure. Among these factors, motivation is the potential needs or mode of thinking, which acts, guides, and chooses individual behavior. Personality is a tendency that inclines a behavior or response to a certain way; Self-image is how an individual views itself. Value is a series of basic concept and orientation of a individual. Compared with knowledge and skill, these are non-intellectual factors.

\subsection{The Origin of Competency}

Competency is a unique thinking mode, working method, and operating process in human resource management. It comes from the needs in organization's strategic development, targets for strengthening competitiveness, and improving actual performance (Yang Zheng, Yin Junming \& Song Yaqin, 2012). The application of competency originated in the early 1950s, when the US State Department found diplomats selected on the basis of intelligence factors to be unsatisfactory. Many of them who seemed to be very outstanding turned out to be very disappointing in practical work. In this case, Dr. MacLellan was invited to help the State Department of USA to design a selecting method which could effectively predict actual performance of candidates. Dr. MacLellan cited a number of studies to criticize the abuse of intelligence tests in the effort to determine the ability of individuals. He further explained that the personality, intelligence, values and other factors, which people subjectively think could decide work performance, did not show the expected effect in reality. Therefore, he stressed getting rid of the theoretical hypothesis proved by unsustainable and subjective judgments so as to return to reality, start from first-hand materials, directly find out those personal conditions and behavior characteristics capable of real impacts on job performance, and make substantial contributions to the improvements of organization efficiency and promotion of personal success. Dr. MacLellan called these individual conditions and behavior characteristics Competency (Liu Hailing, 2007).

\subsection{Common Competency Model}

Competency model is the sum of competencies a certain role needs in a special work. It is a combination of competency characteristics aimed at given position requirements. Different levels of definition and their corresponding levels of description are needed in the position in a model of competency. They determine the key ability and proficiency demanded by a specific task (Mao Cuiyun, 2011). Using the competency model, individuals can independently identify the competency in work demands, work competency advantage, the field to be improved and developments in continue learning and occupation. There are many kinds of theory on the competency model. The most commonly used models are the iceberg model and the onion model.

\subsubsection{The Iceberg Mode}

The iceberg model of American HAY management consulting company is the most famous model about competency (see Figure 1). The iceberg model divides competency into seven aspects: motives, traits, self-image, values, attitudes and social role, knowledge, and behavior. Starting from motives and proceeding from the inside to the outside, the model finally takes behavior as the form of outmost competency, which comprehensively summarizes the structural characteristics of competency. According to this model, "knowledge and skills", similar to the visible tip of an iceberg above the surface of water, are the easiest to change. And "motives and characteristics", comparable to the part hidden under the water, are not easy to touch. They are the most difficult to change or development. Finally, "self-concept" falls between those two.

\subsubsection{The Onion Model}

The onion model summarizes the seven aspects into three levels. Competency is composed of an outer layer and 


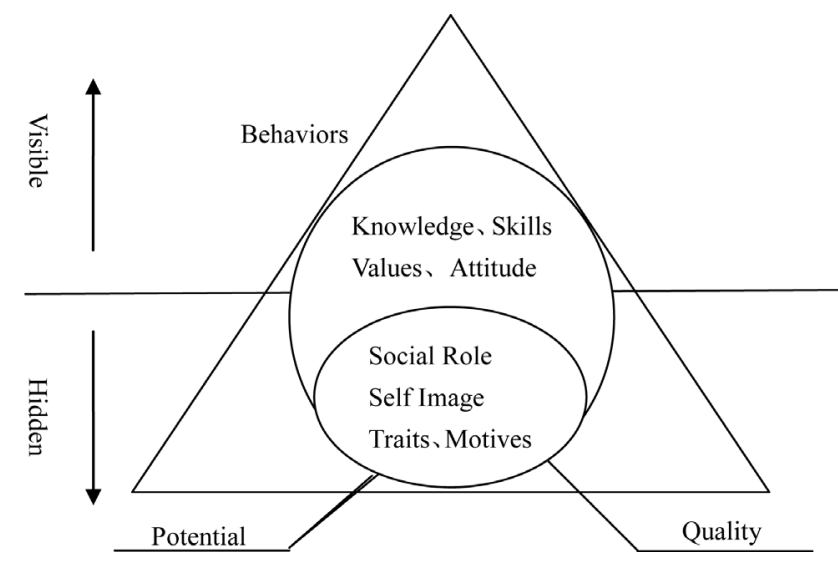

Figure 1. Iceberg competency model.

an inner layer. The layers from the surface to the inner layer and the layers in between are shown in Figure 2. The outer layer consists of the basic skills and knowledge. The inner layer is the core content, namely the motives potential, which is the internal driving force to promote individuals to take action to achieve a goal. The onion model considers the inner two layers difficult to evaluate and regards the outside layer as the easiest to cultivate and evaluate. It is a summary and integration of iceberg model.

\section{The Explanation in GUIDENCE on Competency for CICPAS}

For a CPA in the work environment, competency means his or her ability to complete tasks in accordance with the standards set. Competency is based on the professional quality of CPA. And by professional quality, we mean the professional knowledge, skills, occupation values, ethics and attitudes which a CPA should have to acquire competency. Different professional qualities are required of CPAs in different stages of occupation. So CPAs need to be trained to acquire the qualities. And the qualities should be subject to further maintaining and enhancing through a CPA' lifelong learning.

Professional knowledge is the body of knowledge a CPA should have for accounting, auditing, of the financial, tax, related legal, organizations and enterprises, information technology and other related knowledge.

Professional skills are the abilities to reasonably and effectively use professional knowledge, maintain occupation values, and ethics. They also include attitude in occupation environment. As for intellectual skills, techniques and skills, personal skills, interpersonal and communication skills, organizational and management skills, they, as a matter of course, also count as professional skills.

CPAs are required to have the professional knowledge of accounting, auditing, tax, finance, legal, organizations and enterprises, and information technology.

CPAs need to acquire professional skills in the following five categories: intellectual skills, technology skills, personal skills, interpersonal and communication skills, and management skills.

Professional values, ethics and attitudes, which highlight the moral principles of the CPAs industry, are the unique occupational behaviors and characteristics CPAs needed.

\section{The Necessity of Harmonizing Financial Management Professional Teaching and Professional Competency Training}

Both knowledge and ability provide technical guarantee for the completion of Financial Management. And personalities provide the basic guarantee for giving full play to the knowledge and ability. As shown in Figure 3, financial management teaching includes classroom teaching, professional practice, and other teaching links. Classroom teaching consists of professional knowledge teaching, experiments teaching, case studies, and a variety of seminars and other forms of teaching. Practice link includes relevant knowledge modules, workflow visiting research internships in the real sectors, the post teaching internship, professional internships, and other forms. To sum up, classroom teaching is the basic link, experiment teaching is the supplement, and professional internship is the testing link. Therefore, the interaction of these three links has important implications for the training of occupational competency of the talents in financial management. 


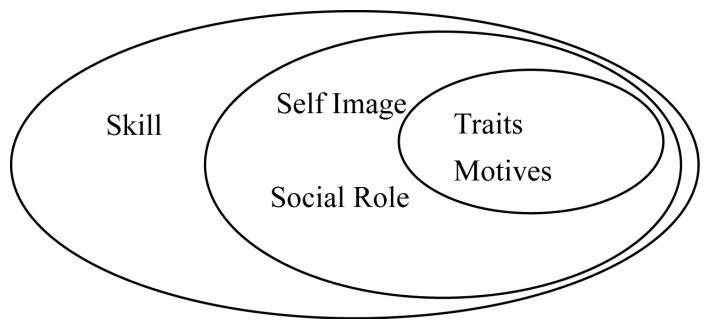

Figure 2. Onion competency model.

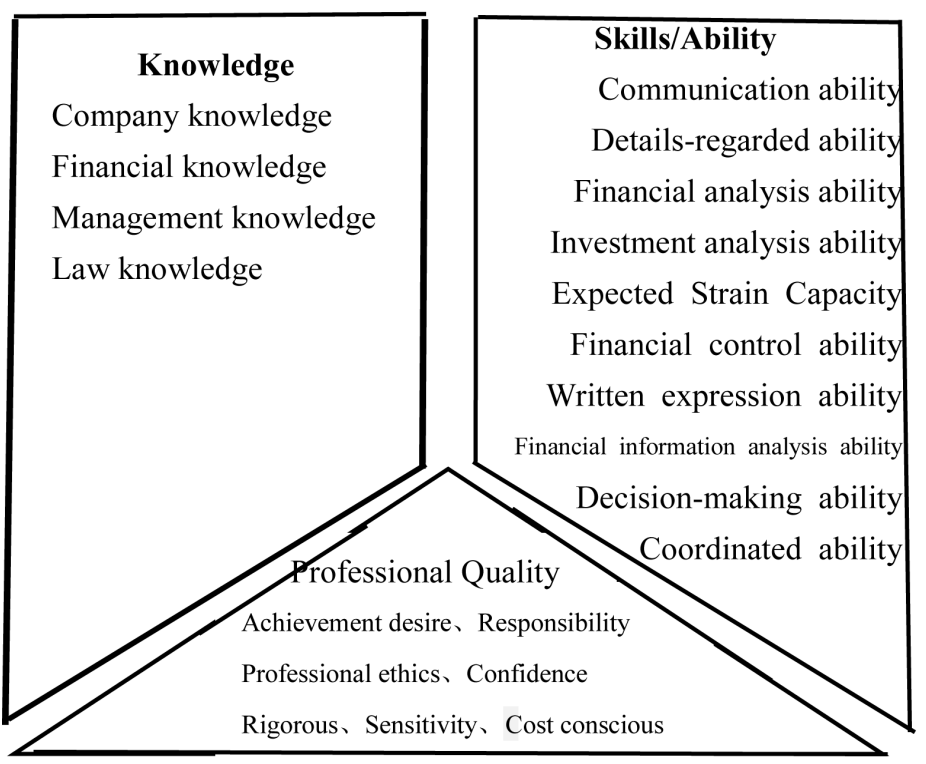

Figure 3. Releationship of knowledge, skills and professional quality.

\subsection{Professional Teaching Is the Main Channel for Occupational Competency Training}

The formation and training of vocational abilities which are influenced by professional teaching, professional fulfillment, Professional morality, environment and other factors, depend on the interaction between professional teaching and practice (Pan Feitong, Wei Hua \& Yang Huihui, 2004). Teachers' teaching not only allows students to gain knowledge and experience, more importantly, it is also of help to the training of students' occupational competency. Hence, professional teaching is the main channel for occupational competency training, and practice is the essential method.

Theoretically, the formation of disaggregate-behavior model depends on the invigorating effect of external stimulus and an individual's social observation of others. External stimulus urges an individual to form a certain behavioral mode in response to the environment and through establishing a solid connection between spontaneous acts of some antecedent and particular stimulus feedback. Classroom teaching allows students to acquire knowledge and learn analytical method from teacher's explanations and demonstrations. In this regard, knowledge and analytical method not only helps students get professional knowledge and skills but also lays foundation for the cultivation of professional ethics. Teachers are disseminators of professional knowledge as well as the shapers of students' formation of good professional ethics.

\subsection{Professional Internship Is the Main Way for Cultivating Students' Vocational Skills}

Vocational skills include intellectual skills, technology skills, personal skills, interpersonal and communication skills, organizational and business management skills. And professional internships can meet the requirements of technology skills, interpersonal skills, and organizational management skills training (He Diankui, 2008). During internships, students can enter a real working environment, come into contact with the actual business work, face a variety of practical issues, learn to think independently, try to analyze, and solve problems. 


\subsection{Ethics Education Is an Important Guarantee of Professional Competence Training}

Due to the demand on talents and job-hunting pressure, inclusion of the education of professional ethics in professional education is urgently needed (An Shiao, 2009). Strengthening the cultivation of modern personality and behavioral modes — such as integrity, independence, innovation, dedication, and self-discipline-are important for all students who face the challenge of globe economy. Also, it is important because it functions to guarantee financial talents' outstanding performance in their future efforts to serve their community and benefit the society (Meng Yan \& Li Ling, 2007).

\section{Pathway to the Harmonization of Financial Management Professional Teaching and Professional Competency Training}

Financial Management Talents Training Pathway Based on the Professional Competency is shown in Figure 4.

\subsection{Establishment of Dynamic Course Modules Based on Demand Orientation}

The curriculum of financial management should highlight the characteristics of their own profession. And these characteristics should be distinguished from the characteristics in other professions. Problems such as repetitive setting of content and unclear division of content should be avoided. We should focus on professional basic courses and professional elective courses setting, professional basic courses, because the focus will enable students go by solid basic principle, and understand the latest development of science and research results (Shao Jingjing, Zong Xuehong \& Jiang Xuemei, 2012). Elective professional courses, as a useful supplement to professional required courses, increase the elasticity course module that reflects the need of industry development. And they guarantee the dynamic docking between curriculum and social demand.

\subsection{Reform of Teaching Methods}

To change the force-feeding method of teaching in which a teacher talks all way in the class and students listen only passively, we should explore and try the heuristic teaching method. Teachers need to inspire students to think deeply, carry out case teaching method, treat the student as center of the class, and simulate actual working conditions, making the student use Interactive exploration to deal with real problems and particular events, carrying out the project learning from an inductive perspective. Professors are required to be able to make full use of modern teaching methods such as computer aided teaching, information technology teaching, to kindle students' enthusiasm.

\subsection{Hiring Practical Experts}

Bringing experts to classroom, hiring enterprises and business experts as teachers to teach courses will ensure

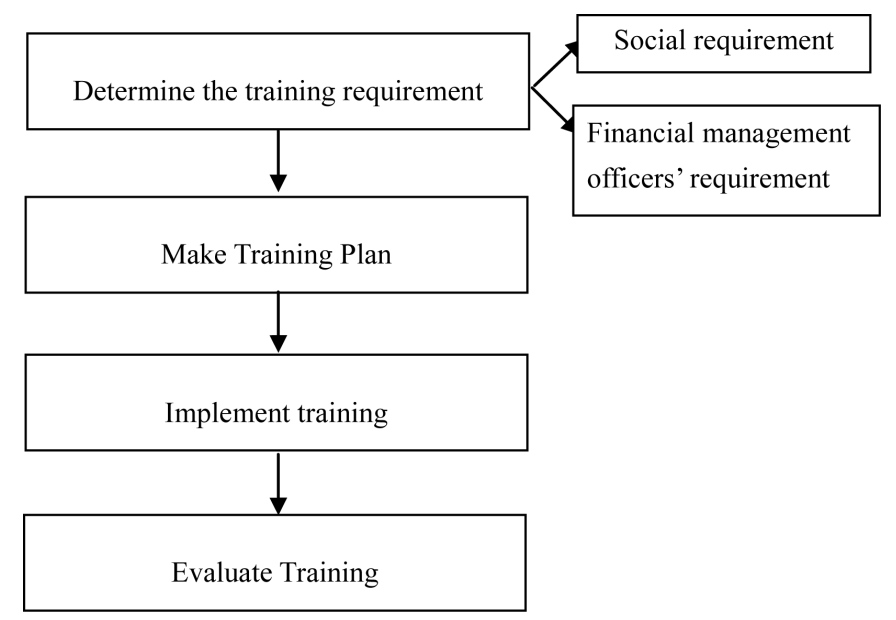

Figure 4. Financial management talents training pathway based on the professional competency. 
that the teaching content are close to real practice. At the same time relevant departments should provide opportunities of continuing education to full-time faculties, and encourage faculties to actively participate in all kinds of faculty training organized by Ministry of Education or relevant professional teaching steering committee. Also they need to create conditions and make arrangements for faculties to take part in social practice in relevant enterprises and institutions (Wang Aijun, 2011). All this would help improve teachers' work performance.

\subsection{Establishing a Multi-Dimensional Students Learning Quality Evaluation}

Traditional evaluation of students' learning quality is based mainly on exams on professional knowledge. But such examinations cannot fully reflect the students' vocational ability. Therefore, it is necessary to appropriately increase assignments of case analysis reports and professional internship reports, professional ethics tests and evaluation of the practice units. Requirements for paper publications should also increase. This is because these supplements are also important to improvement of students' learning quality and useful in professional ability evaluation (Zhou Hong, Zhang Wei, Zong Wenlong \& Yang Ji, 2007; Xiao Mingzheng, 2009).

\section{References}

An Shiyao 安世遨 (2009). Daxuesheng hexie renge goujian de deyu jizhi fenxi 大学生和谐人格建构的德育机制分析. Gaodeng Jiaoyu Yanjiu, 3, 29-33.

He Diankui 贺佃奎 (2008). Dangdai Yingguo gaoxiao de rencai peiyang moshi 当代英国高校的人才培养模式. Gaojiao Yanjiu, 4, 75-78.

Liu Hailing 刘海玲 (2006). Jiyu shengrenli muxing de rencai xuanba yu peiyang 基于胜任力模型的人才选拔与培养. Beijing Youdian Daxue.

Mao Cuiyun 毛翠云 (2011). Chuangye Shengrenli zhonghe Ceping Yanjiu 创业胜任力综合测评研究. Boshi Lunwen, Zhenjiang: Jiangsu Daxue.

Meng Yan 孟焰, \& Li Ling 李玲 (2007). Shichang dingwei xia de kuaijixue zhuanye benke kecheng tixi gaige-jiyu woguo gaoxiao de shijian diaocha zhengju 市场定位下的会计学专业本科课程体系改革一一基于我国高校的实践调查 证据. Kuaiji Yanjiu, 23, 55-63.

Pan Feitong 潘飞童, Wei Hua 卫华, \& Yang Huihui 杨慧辉 (2004). .Meiguo zhuce guanli kuaijishi he zhuce caiwu guanlishi moshi jiqi jiejian 美国注册管理会计师和注册财务管理师模式及其借鉴. Waiguo Jingji yu Guanli, 2, 46-49.

Shao Jingjing 邵晶晶, Zong Xuehong 宗雪红, \& Jiang Xuemei 姜雪梅 (2012). “Yi jiuye wei xiangdao” de gaoxiao rencai peiyang moshi tantao “以就业为向导” 的高校人才培养模式探讨. Zhongguo Rencai, 4, 151-152.

Wang Aijun 王爱军 (2011). Meiguogaoxiao rencai peiyang moshi dui woguo benke jiaoyu de qishi 美国高校人才培养模 式对我国本科教育的启示. Rencai Peiyang, 11, 41-42.

Xiao Mingzheng 萧鸣政 (2009). Rencai pingjia jizhi wenti tansuo 人才评价机制问题探析. Beijing Daxue Xuebao, 5, 31-36.

Yang Zheng 杨政, Yin Junming 殷俊明, \& Song Yaqin 宋雅琴 (2012). Kuaiji rencai nengli xuqiu yu benke kuaiji jiaoyu gaige: Liyi xiangguanzhe de diaochafenxi 会计人才能力需求与本科会计教育改革: 利益相关者的调查分析. Kuaiji Yanjiu, 12, 5-35.

Zhang Junrui 张俊瑞, \& Liu Donglin 刘东霖 (2005). Woguo rencai shichang dui caijing lei rencai xuqiu zhuangkuang de diaocha fenxi 我国人才市场对财经类人才需求状况的调查分析. Kuaiji Yanjiu, 9, 75-79.

Zhou Hong 周宏, Zhang Wei 张巍, Zong Wenlong 宗文龙, \& Yang Ji 杨雯 (2007). Qiye kuaiji renyuan nengli kuaijia yu kuaiji rencai pingjia yanjiu 企业会计人员能力框架与会计人才评价研究. Kuaiji Yaniu, 4, 83-89. 
Scientific Research Publishing (SCIRP) is one of the largest Open Access journal publishers. It is currently publishing more than 200 open access, online, peer-reviewed journals covering a wide range of academic disciplines. SCIRP serves the worldwide academic communities and contributes to the progress and application of science with its publication.

Other selected journals from SCIRP are listed as below. Submit your manuscript to us via either submit@scirp.org or Online Submission Portal.
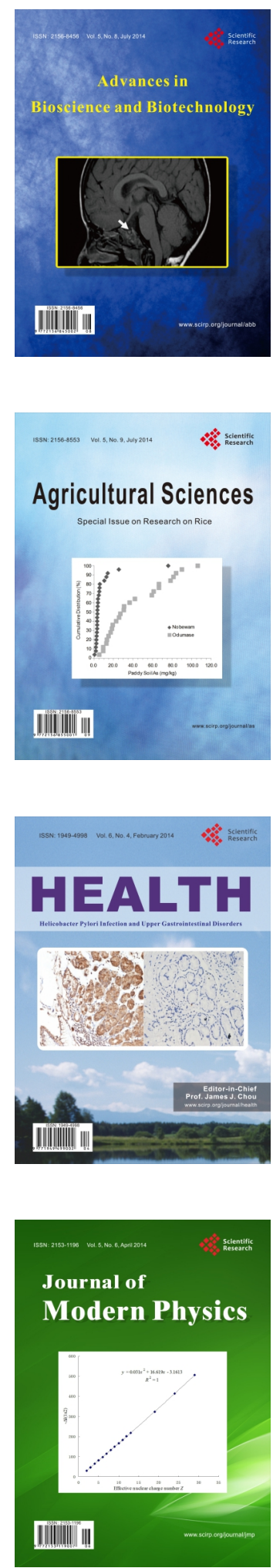
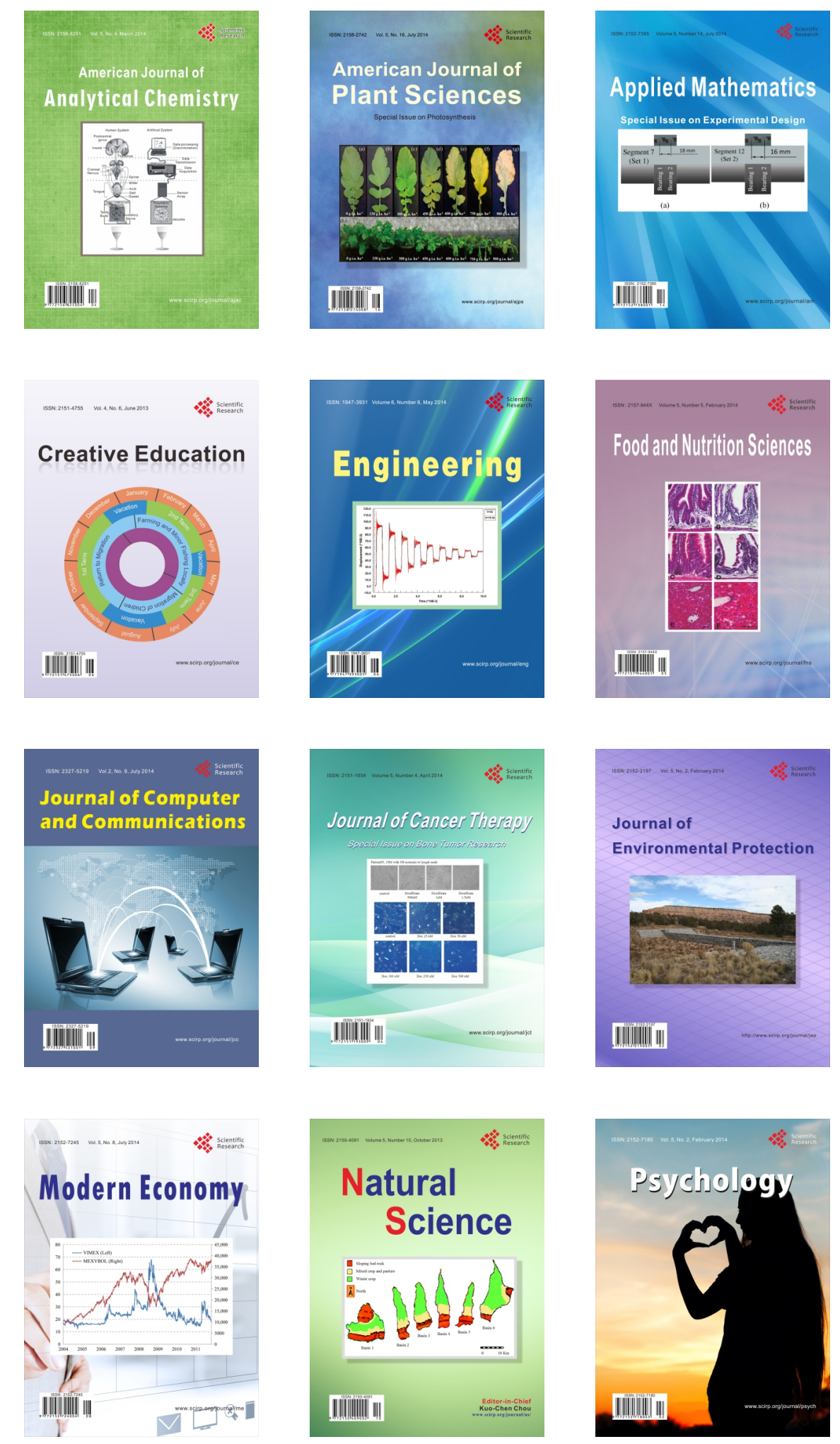